\title{
FUNCTIONAL ANALYSIS AND Advantages OF THE Cell Production System
}

\author{
TAKAKUWA, S.; ICHIKAWA, H. \& MiWA, K.
}

Abstract: The characteristics of the cell production system are described from the standpoint of management and technology. Then, a procedure is proposed to assist in deciding the set of operation elements to be assigned to the designated workers in the assembly line. Performance measures of the system are analyzed to compare with those of the traditional conveyor system, by using a simulation. The cell production system together with RFID/traceability is examined especially from the standpoint of efficiency. It is observed that the cell production system with RFID/traceability is much more efficient than the traditional conveyor systems.

Key words: Cell production system, Just-in-time manufacturing, RFID, Traceability, Simulation
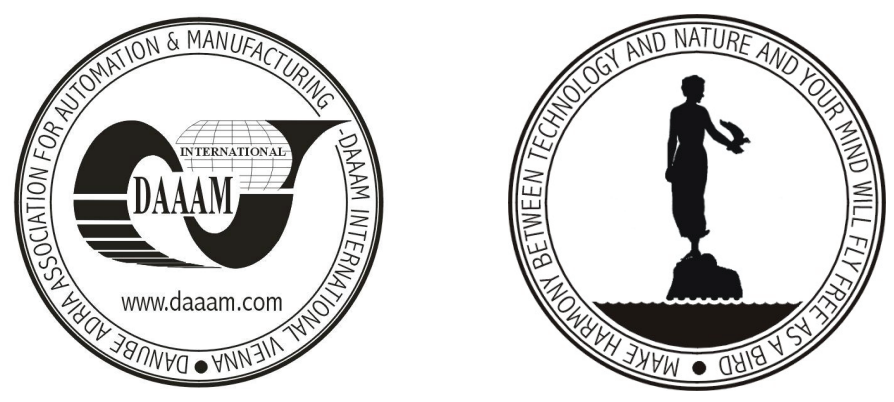

Authors' data: Prof. Takakuwa S.[oemon], Ph.D. Student Ichikawa H.[idetaka], Miwa K.[anna], Graduate School of Economics and Business Administration, Nagoya University, Japan

This Publication has to be referred as: Takakuwa, S.; Ichikawa, H. \& Miwa, K. (2006). Functional Analysis and Advantages of the Cell Production System, Chapter 47 in DAAAM International Scientific Book 2006, B. Katalinic (Ed.), Published by DAAAM International, ISBN 3-901509-47-X, ISSN 1726-9687, Vienna, Austria DOI: $10.2507 /$ daaam.scibook.2006.47 